\section{Granulozyten, basophile}

H. Baum

Institut für Laboratoriumsmedizin, Mikrobiologie und Blutdepot, Regionale Kliniken Holding RKH GmbH, Ludwigsburg, Deutschland

\section{Synonym(e) Basophile}

Englischer Begriff basophilic granulocyte

Definition Reife Zelle der myeloischen Zellreihe mit charakteristischen, auch über dem Zellkern liegenden Granula, die durch basische Farbstoffe gefärbt werden können.

Beschreibung Basophile Granulozyten (s. Abbildung) zeigen einen segmentierten Kern mit einem stark kondensierten Kernchromatin $(1000 \times$, May-Grünwald-Giemsa-Färbung):

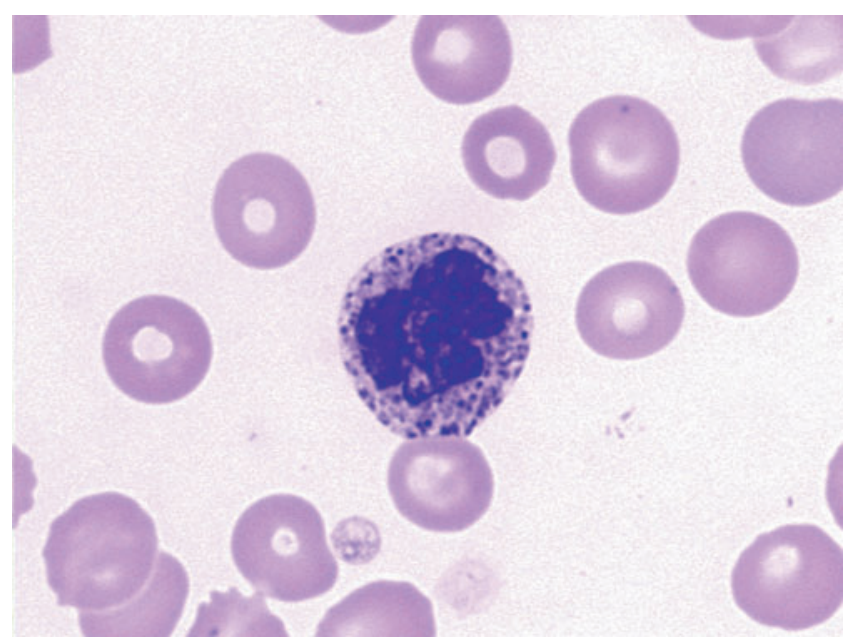

Sie haben meist wenig neutrophiles Zytoplasma und in der - Pappenheim-Färbung sich dunkelblau bis violett anfärbbare (basophile) Granula, die typischerweise auch über dem Kern zu liegen kommen. Die basophilen Granulozyten entstammen der gemeinsamen granulozytären Vorläuferzelle, wobei IL-3 das Hauptstimulans zur Differenzierung ist. Die Aktivierung der basophilen Granulozyten wird durch hochaffine IgE-Rezeptoren vermittelt, die zu einer Exozytose der Granula mit Ausschüttung von Histamin, Leukotrienen, Major Basophilic Protein wie auch Tryptase und anderen Mediatoren führt. Ihre physiologische Rolle ist unbekannt, sie scheinen aber eine aktive Rolle in der Parasitenabwehr zu spielen. Die Anzahl der Basophilen im peripheren Blut ist mit $<1 \%$ sehr gering.

\section{Literatur}

Prussin C, Metcalfe DD (2003) IgE, mast cells, basophils, and eosinophils. J Allergy Clin Immunol 111:486-494 